\title{
KEBERHASILAN HIDUP SETEK PUCUK JABON (Anthocephalus cadamba) DENGAN PEMBERIAN BEBERAPA KONSENTRASI ROOTONE-F
}

\section{(THE SURVIVAL OF KADAM SHOOT CUTTING (Antocephalus cadamba) WITH ADDMITED OF SOME ROOTONE-F CONCENTRATIONS)}

\author{
Ferdiansyah Putra, Indriyanto, dan Melya Riniarti \\ Jurusan Kehutanan, Fakultas Pertanian, Universitas Lampung \\ Jl. Prof. Dr. Sumantri Brojonegoro No.1 Bandar Lampung, 35145 \\ E-mail : p_ferdiansyah@yahoo.com
}

\begin{abstract}
ABSTRAK
Jabon (Anthocephalus cadamba) adalah salah satu jenis pohon yang memungkinkan untuk dikembangkan pada hutan tanaman maupun hutan rakyat untuk memenuhi kebutuhan kayu di Indonesia. Akan tetapi, informasi silvikultur dalam pengembangannya masih terbatas khususnya di bidang penyedian bibit. Penelitian ini bertujuan untuk mengetahui persentase hidup, kemampuan bertunas, dan kemampuan berakar setek pucuk jabon akibat pemberian Rootone-F dengan berbagai konsentrasi. Penelitian mengunakan Rancangan Acak Lengkap dengan empat perlakuan dan lima kali pengulangan. Perlakuan yang digunakan adalah perendaman pangkal setek pucuk dengan berbagai konsentrasi Rootone-F, yaitu 0 ppm, 100 ppm, $200 \mathrm{ppm}$, dan $300 \mathrm{ppm}$. Variabel yang diamati adalah persentase hidup, panjang tunas, diameter tunas, panjang akar setek, dan jumlah daun. Hasil penelitian menunjukkan bahwa pemberian Rootone-F dengan konsentrasi 200 ppm menghasilkan tinggi tunas, panjang akar, dan jumlah daun setek pucuk yang paling baik dibandingkan dengan konsentrasi 0 ppm, 100 ppm, dan 300 ppm. Setek pucuk jabon yang diberi Rootone-F dengan konsentrasi 200 ppm memiliki memiliki persentase hidup $96 \%$, panjang tunas $20,47 \mathrm{~cm}$, panjang akar 19,60 cm, dan jumlah daun 6,18 helai. Berdasarkan hasil penelitian dapat disimpulkan bahwa konsentrasi 200 ppm Rootone-F memberikan pengaruh terbaik.
\end{abstract}

Kata kunci : jabon, Rootone-F, setek pucuk

\section{ABSTRACT}

Kadam (Anthocephalus cadamba) is one types of three possible to develop in plantation forest or public forest to suply log necessity in Indonesia. However, the silviculture information on kadam development is still limited especially in providing nurseries. The objective of this research was to find out survival percentage, shooting ability, and rooting ability of kadam shoot cutting with some concentrations of Rootone-F addmited. This research used completely randomized design with four treatments and five replications. Treatments were soaking the bud of kadam shoot cuttings with some of the following Rootone-F concentrations: 0 ppm, $100 \mathrm{ppm}, 200 \mathrm{ppm}$, and $300 \mathrm{ppm}$. Variables to observe were survival percentages, shoot lengths, shoot diameters, root lengths, and leaf numbers. The results showed that Rootone-F addmited with 200 ppm concentration resulted in the best shoot height, root length, and leaf numbers of kadam shoot cuttings compared with concentrations of 1 ppm, $100 \mathrm{ppm}$, and $300 \mathrm{ppm}$. The kadam shoot cutting with $200 \mathrm{ppm}$ Rootone-F concentration had $96 \%$ survival, $20.47 \mathrm{~cm}$ shoot length, 19.60 root length, and 6.18 leafs. The conclusion was that the concentration of 200 ppm Rootone-F gives the best results.

Key words : kadam, Rootone-F, shoot cutting 


\section{PENDAHULUAN}

Kebutuhan kayu di Indonesia setiap tahun meningkat dan diperkirakan kebutuhan kayu nasional Indonesia mencapai lebih dari 60 juta $\mathrm{m}^{3}$. Lima puluh persen dari kebutuhan kayu tersebut digunakan sebagai bahan baku industri kayu lapis atau plywood. Pada tahun 70-an, $100 \%$ industri perkayuan mengandalkan hutan alam sebagai sumber pasokan bahan baku. Namun, akibat terjadinya kerusakan hutan alam dengan laju kerusakan mencapai 2,87 juta ha per tahun, membuat pasokan kayu berkurang drastis (Halawane dkk., 2011). Akhirnya industri perkayuan harus berpaling pada kayu hasil budidaya, baik dari hutan tanaman milik negara maupun hutan rakyat.

Jabon (Anthocephalus cadamba ) adalah salah satu jenis pohon yang dapat dikembangkan pada hutan tanaman milik negara dan pada hutan rakyat karena memiliki pertumbuhan yang cepat dengan kualitas kayu yang bagus sehingga dapat dimanfaatkan sebagai bahan baku kayu perkakas, kayu bakar, kayu lapis, papan partikel, dan kertas. Informasi silvikultur yang masih terbatas adalah salah satu kendala dalam pengembangan jabon, khususnya informasi di bidang penyediaan bibit.

Ketersedian bibit jabon dapat diperoleh dengan cara perkembangbiakan secara generatif dan vegetatif. Kelemahan perkembangbiakan jabon secara generatif adalah viabilitas benihnya yang cenderung menurun. Benih yang disimpan kurang dari tiga bulan viabilitasnya menurun mencapi 60--70\%, dan benih yang sudah disimpan lebih dari tiga bulan tergolong benih yang kurang baik untuk dibibitkan (Mulyana dkk; 2010).

Oleh karena itu, salah satu alternatif untuk pengadaan bibit adalah perkembangbiakan secara vegetatif misalnya dengan setek.

Ada beberapa metode setek, salah satunya adalah setek pucuk. Keuntungan dari perkembangbiakan melalui setek pucuk adalah dapat dilakukan kapan saja sehingga tidak bergantung pada musim pohon jabon berbuah. Di samping itu, bahan setek dapat diambil dari anakan pohon-pohon yang unggul, sehingga akan diperoleh bibit hasil setek yang juga unggul (Mansur dan Tuheteru, 2010). Untuk mendukung keberhasilan hidup setek pucuk umumnya digunakan Zat Pengatur Tumbuh (ZPT). Salah satu ZPT yang biasa digunakan yaitu Rootone-F.

Rootone-F adalah salah satu ZPT eksogen yang termasuk dalam kelompok auksin. Rootone-F dapat mempercepat dan memperbanyak keluarnya akar, sehingga penyerapan air dan hara oleh akar dapat berjalan dengan baik (Kusumo, 1994). Namun konsentrasi RootoneF yang tepat untuk memperoleh keberhasilan hidup setek pucuk jabon belum diketahui, sehingga perlu dilakukan penelitian tentang keberhasilan hidup setek pucuk jabon dengan pemberian beberapa konsentrasi Rootone-F.

Tujuan penelitian adalah untuk (1) mengetahui persentase hidup setek pucuk jabon akibat pemberian Rootone-F dengan berbagai konsentrasi, dan (2) mengetahui kemampuan pertumbuhan pucuk, pertumbuhan akar, pertumbuhan diameter, dan pertumbuhan jumlah daun setek pucuk jabon dengan pemberian Rootone-F dengan berbagai konsentrasi.

Hipotesis penelitian yang diajukan yaitu (1) konsentrasi Rootone-F 200 ppm mempunyai pengaruh terbaik terhadap persentase hidup setek pucuk jabon, dan (2) pemberian Rootone-F dengan konsentrasi 200 ppm menghasilkan pertumbuh pucuk, pertumbuhan akar, pertumbuhan diameter, dan pertumbuhan jumlah daun yang terbaik pada setek pucuk jabon dibandingkan dengan konsentrasi 0 ppm, 100 ppm, dan 300 ppm.

\section{METODE PENELITIAN}

Penelitian dilaksanakan pada April sampai dengan Juni 2012 di Perum Polda 2 Gang Mawar no. 7 Kelurahan Pinang Jaya, Kecamatan Kemiling, Kota Bandar Lampung. 
Alat yang digunakan adalah polibag ukuran $10 \mathrm{~cm}$ x $15 \mathrm{~cm}$, ember, golok, pisau, kotak plastik, sprayer, cangkul, label, alat tulis, plastik sungkup, paranet $70 \%$, kaliper, penggaris, hygrometer, gelas ukur, dan lembar pengamatan. Bahan yang digunakan untuk penelitian adalah pucuk jabon, media penumbuh setek berupa campuran pasir sungai dan arang sekam padi dengan perbandingan $3: 1$, air, dan Rootone-F.

Penelitian dilakukan dengan menggunakan Rancangan Acak Lengkap (RAL) dengan empat perlakuan yaitu perendaman dengan Rootone-F berkonsentrasi 0 ppm, 100 ppm, 200 ppm, dan 300 ppm. Masing-masing perlakuan diulang lima kali. Setiap unit percobaan terdiri dari lima setek pucuk jabon, sehingga diperlukan sebanyak 100 setek pucuk jabon.

Bedeng semai terbuat dari kasau dengan ukuran $3 \mathrm{~m} \times 2 \mathrm{~m} \times 2 \mathrm{~m}$, kemudian ditutupi dengan paranet dengan intensitas cahaya $70 \%$. Sungkup berupa kerangka kasau yang ditutup plastik transparan, gunanya untuk menutup setek pucuk yang baru disemai, agar kelembapan udara tetap tinggi. Bentuk sungkup berupa balok dengan ukuran $1,5 \mathrm{~m} \mathrm{x} \mathrm{1,5m} \mathrm{x} 1 \mathrm{~m}$.

Konsentrasi Rootone-F yang diaplikasikan meliputi 0 ppm (kontrol), 100 ppm, 200 ppm, dan 300 ppm. Penyiapan larutan Rootone-F dilakukan dengan cara :

1. Konsentrasi 0 ppm tanpa Rootone-F.

2. Konsentrasi $100 \mathrm{ppm}$, adalah campuran $100 \mathrm{mg}$ Rootone-F dengan 1 liter air.

3. Konsentrasi 200 ppm, adalah campuran 200 mg Rootone-F dengan 1 liter air.

4. Konsentrasi 300 ppm, adalah campuran 300 mg Rootone-F dengan 1 liter air.

Media penumbuh setek yang digunakan untuk menyemai setek pucuk jabon adalah campuran pasir sungai dan arang sekam padi dengan perbandingan 3:1. Media penumbuh dibesihkan dari kotoran dan gulma serta digemburkan, kemudian diberi dengan fungisida dithane sebanyak 5 gram dan pestisida furadan sebanyak 10 gram secara merata. Media penumbuh tersebut ditutup terpal dan dibiarkan selama 1 minggu. Setelah 1 minggu media tersebut dimasukkan ke dalam polibag berukuran $10 \mathrm{~cm}$ x $15 \mathrm{~cm}$.

Bahan setek pucuk diambil di Way Kandis. Pengambilan pucuk jabon dilakukan dengan 3 tahapan yaitu.

1. Cabang atau ranting yang secara fisiologis muda, memiliki batang yang lurus dipangkas kemudian diambil pucuknya dengan jumlah ruas sebanyak dua atau lebih.

2. Pucuk yang telah dipilih tersebut dipotong dengan menggunakan pisau yang tajam dengan irisan miring. Panjang setek cukup $15 \mathrm{~cm}$ dipotong tepat di bawah buku-buku batang dengan diameter batang kira-kira $0,5 \mathrm{~cm}$.

3. Bahan setek pucuk yang telah diambil tersebut dimasukkan ke dalam wadah kotak plastik kemudian ditutup.

Penyemaian setek pucuk jabon dilakukan dengan cara sebagai berikut.

1. Setek pucuk jabon disemai pada media penumbuh akar dalam polibag. Sebelumnya pangkal setek direndam ke dalam larutan Rootone-F sesuai dengan konsentrasi yang telah ditetapkan selama 15 menit.

2. Media penumbuh akar di sekeliling setek ditekan supaya padat sehingga pada saat penyiraman media tersebut tidak hancur. Batang setek harus berdiri tegak sehingga pertumbuhan vertikal ke atas dan akar dapat tumbuh dengan baik.

3. Setek pucuk jabon yang telah disemai ke dalam polibag kemudian disusun dalam bedeng sesuai dengan tata letak perlakuan pada rancangan acak lengkap.

4. Polibag yang telah disusun tersebut selanjutnya ditutup dengan sungkup plastik transparan yang telah disiapkan sebelumnya. Sungkup plastik diperlukan untuk menjaga kelembapan lingkungan.

Pemeliharaan meliputi kegiatan penyiraman dan penyiangan. Penyiraman dilakukan bila media penumbuh akar terlihat kering atau tidak lembab. Kelembapan diukur dengan hygrometer. Penyiraman dilakukan dengan cara menyemprotkan air dengan sprayer. 
Penyiangan dilakukan secara rutin 3 hari sekali, yaitu menghilangkan gulma yang tumbuh bersama setek pucuk jabon pada media penumbuh setek dengan cara mekanik.

Variabel yang diamati meliputi persentase hidup, pertumbuhan panjang tunas, pertumbuhan diameter, panjang akar akar, dan jumlah daun setek pucuk jabon.

Data yang didapat dari hasil pengamatan dicatat. Homogenitas variansnya diuji dengan uji Bartlett, bila data yang diuji telah homogen data kemudian diolah dengan analisis sidik ragam. Untuk mengetahui perbedaan pengaruh antara perlakuan dilakukan uji Beda Nyata Jujur (BNJ). Semua uji tersebut dilakukan pada taraf nyata 5\% (Hanafiah, 2004).

Homogenitas ragam diuji menggunakan uji Bartlett, dan hasil perhitungannya disajikan

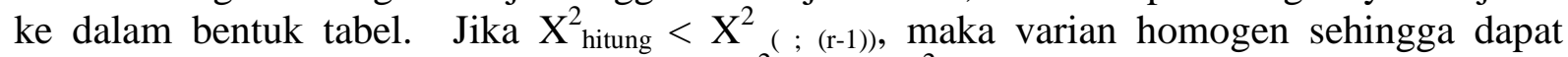

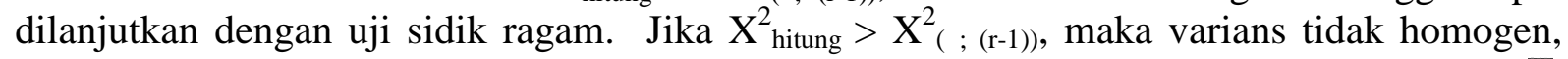
harus dilakuakan transformasi data. Transformasi data yang digunakan, misalnya dengan $\sqrt{Y}$ ,$\frac{1}{Y}$, atau $\log (\mathrm{Y}+1)$ (Hanafiah, 2004).

Analisis ragam dimaksudkan untuk menguji hipotesis tentang pengaruh faktor perlakuan terhadap setiap variabel yang diamati. Jika Fhitung $>$ Ftabel, maka perlakuan yang diberikan berpengaruh nyata terhadap pertumbuhan setek pucuk jabon. Kemudian untuk menyelidiki perlakuan-perlakuan apa saja yang berbeda nyata, dilakukan pembanding nilai rata-rata tiap perlakuan dengan uji BNJ. Jika $\mathrm{F}$ hitung $\leq \mathrm{F}$ tabel, maka tidak ada pengaruh nyata dari keragaman perlakuan yang diberikan.

Uji Beda Nyata Jujur dilakukan untuk menunjukkan perbedaan pengaruh antar perlakuan terhadap setiap variabel yang diamati.

\section{HASIL DAN PEMBAHASAN}

Analisis ragam pada Tabel 1 memperlihatkan bahwa pemberian Rootone-F dengan berbagai konsentrasi memberikan pengaruh yang berbeda nyata pada taraf nyata $5 \%$ terhadap parameter panjang tunas, panjang akar, dan jumlah daun setek pucuk jabon, tetapi memberikan pengaruh yang tidak berbeda nyata terhadap parameter persentase hidup dan diameter tunas setek pucuk. Adapun hasil analisis lanjut menggunakan uji BNJ dapat dilihat pada Tabel 2.

Dari Tabel 1 terlihat konsentrasi Rootone-F 0 ppm, 200 ppm,100 ppm, dan 300 ppm masing-masing menunjukkan tidak adanya perbedaan yang nyata terhadap persentase hidup.

Berdasarkan hasil uji BNJ, seperti yang dapat dilihat pada Tabel 2, diketahui bahwa panjang tunas yang diberi Rootone-F dengan konsentrasi 200 ppm memberikan pengaruh yang berbeda nyata dibandingkan dengan perlakuan lainnya. Panjang tunas dengan pemberian Rootone-F 200 ppm adalah $20,47 \mathrm{~cm}$.

Berdasarkan analisis ragam pada Tabel 1 Pemberian Rootone-F tidak memberikan pengaruh yang nyata terhadap pertumbuhan diameter batang.

Pemberian Rootone-F 200 ppm merupakan perlakuan terbaik pada parameter panjang akar. Berdasarkan uji BNJ diketahui Rootone-F 200 ppm memberikan pengaruh yang berbeda nyata dengan perlakuan lainnya dengan menghasilkan panjang akar rata-rata $19,60 \mathrm{~cm}$.

Perlakuan Rootone-F dengan konsentrasi 200 ppm adalah perlakuan terbaik untuk parameter jumlah daun. Perlakuan Rootone-F 200 ppm mampu menghasilkan rata-rata jumlah daun 6,18 helai.

Menurut Wirawan (1988) kandungan Rootone F adalah senyawa IBA dan NAA yang merupakan senyawa yang memiliki daya kerja seperti auksin (IAA) yaitu pada konsentrasi yang tepat akan meningkatkan pembelahan, perpanjangan sel dan diferensiasi dalam bentuk perpanjangan ruas. 
Auksin berperan mengaktifasi pompa proton (ion $\mathrm{H}^{+}$) yang terletak pada membran plasma sehingga menyebabkan $\mathrm{pH}$ pada bagian dinding sel lebih rendah dari biasanya, yaitu mendekati $\mathrm{pH}$ pada membran plasma (sekitar $\mathrm{pH} 4,5$ dari normal $\mathrm{pH} 7$ ). Aktifnya pompa pronton tersebut dapat memutuskan ikatan hidrogen diantara serat selulosa dinding sel. Putusnya ikatan hidrogen menyebabkan dinding mudah merenggang sehingga tekanan dinding sel akan menurun dan dengan demikian terjadilah pelenturan sel, sehingga pemanjangan dan pembesaran sel dapat terjadi (Catala dkk., 2000).

Untuk meningkatkan laju pertumbuhan tanaman, pemberian ZPT perlu memperhatikan konsentarasi yang tepat. Hal ini sesuai dengan pendapat Abidin (1983) bahwa pemberian ZPT yang berlebihan pada tanaman akan menghambat pertumbuhan tanaman. Pendapat ini juga ditunjang oleh Wattimena (1987) bahwa respon tanaman atau bagian tanaman terhadap hormon yang diberikan akan berbeda-beda tergantung jenis tanaman, umur, keadaan lingkungan, tingkat perkembangan fisologis terutama kandungan hormon endogen dan unsur hara.

Pemberian Rootone-F dengan berbagai konsentrasi tidak memberikan pengaruh yang signifikan terhadap persentase hidup jabon. Rata-rata persentase tumbuh jabon mencapai 87 $\%$. Hal serupa juga telah dibuktikan oleh Nadiroh (2003) yang melakukan penelitian mengenai pertumbuhan setek pucuk senteng (Azadirachta excelca) pada berbagai dosis Rootone-F dan media. Penelitan dilakukan dengan pengolesan Rootone-F dengan berbagai dosis. Penelitian menunjukan bahwa pemberian Rootone-F tidak berpengaruh nyata terhadap persentase tumbuh setek senteng.

Tabel 1. Rekapitulasi hasil analisis ragam untuk semua variabel.

\begin{tabular}{|c|c|c|c|c|c|c|}
\hline \multirow[b]{2}{*}{ Perlakuan } & \multicolumn{5}{|c|}{ Nilai F hitung pada tiap variabel } & \multirow[b]{2}{*}{$\mathrm{F}_{3 ; 16 \quad 5 \%}$} \\
\hline & $\begin{array}{l}\text { Persentase } \\
\text { hidup }\end{array}$ & $\begin{array}{l}\text { Pertumbuhan } \\
\text { panjang tunas }\end{array}$ & $\begin{array}{c}\text { Pertumbuhan } \\
\text { diameter setek }\end{array}$ & Panjang akar & Jumlah daun & \\
\hline $\begin{array}{c}\text { Zat } \\
\text { pengatur } \\
\text { tumbuh }\end{array}$ & $2,250 \mathrm{tn}$ & $16,320 *$ & $0,086 \mathrm{tn}$ & $10,116^{*}$ & $15,143^{*}$ & 3,239 \\
\hline KK $(\%)$ & 10,28 & 6,98 & 3,4 & 8,92 & 8,76 & \\
\hline
\end{tabular}

Keterangan:

$\mathrm{KK}=$ koefisien keragaman

* = berpengaruh nyata pada taraf $5 \%$

tn $=$ tidak nyata

Tabel 2. Rekapitulasi nilai tengah setiap variabel yang diamati dan uji BNJ terhadap perlakuan yang berpengaruh nyata pada taraf nyata $5 \%$.

\begin{tabular}{|c|c|c|c|c|c|}
\hline \multirow[b]{2}{*}{$\begin{array}{c}\text { Konsentrasi Rootone- } \\
\text { F }\end{array}$} & \multicolumn{5}{|c|}{ Nilai tengah setiap variabel yang diamati } \\
\hline & $\begin{array}{c}\text { Persentase } \\
\text { hidup } \\
(\%)\end{array}$ & $\begin{array}{c}\text { Pertumbuhan } \\
\text { panjang tunas } \\
(\mathrm{cm})\end{array}$ & $\begin{array}{c}\text { Pertumbuhan } \\
\text { Diameter setek } \\
(\mathrm{mm})\end{array}$ & $\begin{array}{l}\text { Panjang akar } \\
\text { (cm) }\end{array}$ & $\begin{array}{l}\text { Jumlah daun } \\
\text { (helai) }\end{array}$ \\
\hline $0 \mathrm{ppm}$ & $84 \mathrm{a}$ & $16,03 \mathrm{cb}$ & $4,30 \mathrm{a}$ & $15,44 \mathrm{~b}$ & $4,31 \mathrm{cb}$ \\
\hline $100 \mathrm{ppm}$ & $84 \mathrm{a}$ & $18,01 \mathrm{~b}$ & $4,32 \mathrm{a}$ & $16,58 \mathrm{~b}$ & $5,40 \mathrm{ca}$ \\
\hline 200 ppm & 96 a & $20,47 \mathrm{a}$ & $4,35 \mathrm{a}$ & $19,60 \mathrm{a}$ & $6,18 \mathrm{a}$ \\
\hline $300 \mathrm{ppm}$ & $84 \mathrm{a}$ & $15,65 \mathrm{c}$ & $4,33 \mathrm{a}$ & $14,87 \mathrm{~b}$ & $4,90 \mathrm{~b}$ \\
\hline BNJ 5\% & 16,2 & 2,217 & 0,255 & 2,686 & 0,978 \\
\hline
\end{tabular}

Keterangan: huruf yang sama pada kolom yang sama tidak berbeda nyata pada taraf nyata 5\% 
Hal ini diduga karena persentase hidup setek pucuk jabon tidak hanya dipengaruhi oleh pemberian ZPT, melainkan juga dipengaruhi oleh beberapa faktor pendukung lainnya. Faktor-faktor yang dapat mempengaruhi keberhasilan hidup setek pucuk yaitu jenis tanaman, umur bahan stek, media, drainase media, intensitas cahaya, teknik pengguntingan dan konsentrasi hormon yang digunakan (Omon dkk., 1989)

Pemberian Rootone-F pada konsentrasi 0 ppm, 100 ppm, 200 ppm pada setek pucuk jabon menghasilkan pertumbuhan panjang tunas jabon yang semakin meningkat, akan tetapi pemberian Rootone-F dengan konsentrasi 300 ppm kepada setek pucuk jabon menunjukan laju pertumbuhan yang menurun dibandingkan dengan tanpa pemberian Rootone-F. Hal ini diduga bahwa bahwa pemberian Rootone-F dengan konsentrasi 300 ppm telah melebihi batas konsentrasi yang dibutuhkan oleh setek pucuk jabon.

Pertumbuhan panjang tunas yang tidak mengalami peningkatan tersebut diduga akibat konsentrasi Rootone-F yang berlebihan, karena konsentrasi auksin yang tinggi akan mendorong terbentuknya zat penghambat etilen yang dapat membuat pertumbuhan sel terhambat (Abidin, 1983).

Menurut Salisbury dan Ross (1995) mengemukakan kandungan etilen menyebabkan sel korteks mensintesis selulase, yaitu enzim yang menghidrolisis selulosa dan sebagian menyebabkan penguraian dinding sel. Dengan demikian pertumbuhan tunas menjadi terhambat.

Berbeda dengan panjang tunas, diameter setek pucuk jabon tidak mengalami adanya perbedaan yang signifikan. Hal ini diduga dikarnakan waktu penelitian yang singkat sehingga membuat laju pertumbuhan diameter belum menunjukkan adanya perbedaan yang signifikan. Hampir semua tanaman tingkat tinggi mengikuti pola pertumbuhan yang sama yakni membentuk kurva sigmoid dimana pertumbuhan relatif lambat pada fase awal (bibit) dan meningkat cepat pada fase sebelum berbunga dan kembali menurun setelah pase berbunga. Hal tersebut juga yang diduga mendasari mengapa pertumbuhan diameter pada penelitian ini belum menunjukan adanya perbedaan yang signifikan. Pendapat ini juga didukung pernyataan Wattimena (1987) bahwa keberhasilan pemberian zat pengatur tumbuh tidak selalu ditentukan oleh konsentrasi zat pengatur tumbuh dan waktu aplikasinya, melainkan juga ditentukan oleh fase pertumbuhan tanaman.

Pemberian Rootone-F 200 ppm memberikan pengaruh yang nyata terhadap pertumbuhan panjang akar, hal tersebut diduga konsentrasi Rootone-F 200 ppm paling efektif untuk mempercepat terjadinya pembelahan sel, perpanjangan sel, dan diferensiasi sel, sehingga pertumbuhan tunas dan daun lebih cepat dibandingkan konsentrasi lainnya.

Hal ini didukung oleh pendapat Gadner dkk. (1991) yang mengemukakan bahwa kadar auksin yang optimal akan memacu pertumbuhan dan perkembangan awal akar. Konsentrasi yang optimal juga telah dibuktikan oleh penelitian Putileihalat (2001) sebelumnya yang melibatkan penggunaan zat pengatur tumbuh Rootone- $F$ terhadap tanaman pulai gading (Alstonia scholaris) dengan cara oles menemukan pada tingkat dosis $60 \mathrm{mg}$, zat pengatur tumbuh Rootone-F memberikan hasil yang terbaik untuk pertumbuhan dan perkembangan tunas dan akar stek gading.

Perlakuan terbaik untuk parameter jumlah daun adalah perlakuan Rootone-F 200 ppm yang menghasilkan jumlah daun terbanyak yaitu 6,18 helai. Hal ini berarti bahwa pemberian ZPT Rootone F pada konsentrasi 200 ppm telah memadai untuk pertumbuhan jumlah daun setek pucuk jabon. Proses pembentukan daun dimulai dari adanya pembelahan sel di daerah lateral apeks sehingga terjadi tonjolan yang disebut penyangga daun yang kemudian tumbuh menjadi daun (Fahn, 1992). Peningkatan jumlah daun setek pucuk jabon berhubungan dengan aktivitas pembelahan sel. Pemberian Rootone-F dengan konsentrasi yang tepat diduga membuat pembelahan sel pada setek pucuk jabon menjadi optimal. Optimalnya 
pembelahan sel yang terjadi pada setek pucuk jabon inilah yang membuat jumlah daun pada setek pucuk jabon menjadi meningkat.

\section{SIMPULAN}

Berdasarkan hasil penelitian dan pembahasan dapat disimpulkan sebagai berikut.

1. Pemberian Rootone-F dengan berbagai konsentrasi tidak berpengaruh nyata terhadap persentase hidup setek pucuk jabon. Rata-rata keseluruhan persentase hidup setek pucuk jabon yang dihasilkan adalah $87 \%$.

2. Rootone-F berkonsentrasi 200 ppm memberikan laju pertumbuhan terbaik terhadap kemampuan bertunas, pertumbuhan akar, dan pertumbuhan jumlah daun setek pucuk jabon.

\section{DAFTAR PUSTAKA}

Abidin, Z. 1983. Dasar-dasar Pengetahuan Tentang Zat Pengatur Tumbuh. Buku. Angkasa. Bandung. $85 \mathrm{p}$.

Aryulina, D., C. Muslim., S. Manaf., dan E. W. Winarni. 2006. Biologi 1 SMA dan MA Untuk Kelas X. Buku. Erlangga. Jakarta. 352 p.

Catala, C., J. K. C. Rose., dan A. B. Bennett. 2000. Auxin-regulated genes encoding cell wallmodifying proteins are expressed during early tomato fruit growth-plant. Artikel. Plant Physiology. California. 122 (2): 527 - 534 p.

Fahn, A. 1992. Anatomi Tumbuhan. Buku. Gadjah Mada Univesity Press. Yogyakarta. 943 p.

Gardner, P. dan Mitchell. 1991. Fisiologi Tanaman Budidaya. Buku. Universitas Indonesia. Jakarta. 428 p.

Halawane, J. E., N. Hanif., dan J. Kinho. 2011. Prospek Pengembangan Jabon Merah (Anthocephalus macrophyllus) Solusi Kebutuhan Kayu Masa Depan. Buku. Balai Penelitian Kehutanan Manado. Manado. 63 p.

Hanafiah, K. A. 2004. Rancangan Percobaan Teori dan Aplikasi. Buku. PT Raja Grafindo Persada. Jakarta. 259 p.

Kusumo. 1994. Zat Pengatur Tumbuh. Buku. CV Yasaguna. Jakarta. 97 p.

Mansur, I. dan F. D. Tuheteru. 2010. Kayu Jabon. Buku. Penebar Swadaya. Jakarta. 123 p.

Nadiroh. 2003. Pertumbuhan setek pucuk senteng (Azadirachta excelca) pada berbagai dosis Rootone-F dan media. Skripsi. Institut Pertanian Bogor. Bogor. 70 p.

Omon, R. M., A. P. Mas'ud., dan Harbagung. 1989. Pengaruh media padat dan Rootone-F terhadap pertumbuhan akar stek batang (Shorea Palyandra). Buletin Kehutanan. Balai Penelitian Kehutanan Pematang Siantar. Sumatra Utara. 5(3): 105-202 p.

Puttileihalat, M. 2001. Pengaruh Rootone-F dan ukuran diameter stek terhadap pertumbuhan tunas dari stek pulai gading (Alstonia scholaris). Skripsi. Universitas Pattimura. Maluku. 60 p.

Salibury, F. B. dan C. W. Ross. 1995. Fisiologi Tumbuhan Jilid 3. Buku. ITB. Bandung. 343 p.

Wattimena, G. A. 1987. Zat Pengatur Tumbuh Tanaman. Buku. IPB. Bogor. 254 p.

Wirawan, G. N. 1988. Mari Menanam Panili (Vanilla planifolia Andrews). Buku. Simplex. Jakarta. 71 p. 
Vol. 2 No. 2, Mei 2014 (33-40)

Halaman ini sengaja dikosongkan 